\title{
Nü Peride Romanına Yeni Tarihselci Bir Yaklaşım
}

\author{
Yasemin Ulutürrk* \\ Sağlık Bilimleri Üniversitesi, İstanbul, Türkiye
}

Makale Bilgileri /

Article Info:

Gönderim / Received: 21.11.2017

Kabul / Accepted:

26.01.2018

Corresponding Author:

Sağlık Bilimleri

Üniversitesi,

İstanbul, Türkiye

vasemin.uluturk@sbu.edu.tr

\section{Öz}

Postmodernizmin edebî metinleri çözümleme yöntemleri ile benzerlik gösteren Yeni Tarihselcilik kuramı, tarihin kurgusallık boyutunu tartışmaya açar. Yeni Tarihselcilik "metnin dışında hiçbir şey yoktur" bakış açısına odaklanarak tarih ile edebî metin arasındaki sınırın ortadan kalktığını savunan bir kuramdır. Bu kuram bağlamında, çalışmamızın esasını oluşturan eser, Nü Peride adlı tarihî romandır. Bu eserde, tarih ile romanın metinsellik bakımından birbirine yaklaştırıldığı ve Yeni Tarihselcilik kuramı ile de oldukça zengin örnekler sunulduğu görülmektedir. Geleneksel tarih anlayışını reddeden Yeni Tarihselcilere göre tarih metinleri, sübjektif olarak ortaya konulan eserlerdir. Dolayısıyla tarihçi de tıpk1 romanc1 gibi kendi ideolojisi ve bakış açısının tesirinde kalarak nesnellikten uzaklaşır ve öznel bir anlatıma yaklaşır. Nitekim onlara göre tarihçilerin ele aldıkları dönemlerde bile zorunlu bir seçim yapmak durumunda kalmaları, hiçbir zaman objektif olamayacaklarını göstermektedir. Bu nedenle çalışmanın amacı, postmodern tarih romanı olan Nü Peride'nin "Yeni Tarihselci" bir yaklaşım ile kaleme alınmış olduğunu ve tarih disiplinine farklı bir bakış açısı oluşturan bu kuramın romana nasıl tezahür ettiğini ortaya koymaktır.

Anahtar Kelimeler: Postmodernizm, Yeni Tarihselcilik, Nü Peride, Hakan Akdoğan.

\section{A New Historical Approach to the Nü Peride Novel}

\begin{abstract}
The theory of New Historicism, which resembles the methods of analyzing literary texts of postmodernism, opens the debate on the dimensionality of history. New Historicalism is nothing other than the "text" is a theory that advocates that the boundary between history and literary text ceases to exist, focusing on the point of view. Nü Peride is the text analysis of our study is in the novel. In this work, it is seen that the history and the novel are close to each other in terms of textuality and very rich examples are presented in the context of New Historicalism. New Historians deny the traditional understanding of history, the person who writes the history text,
\end{abstract}


will be influenced by his own ideology and viewpoint, and will reflect on his work and will move away from his objectivity. As a matter of fact, according to them, the necessity of making a compulsory choice even in the periods that historians deal with shows that they can never be objective. For the reason, the aim of this study is to demonstrate how the postmdern history novel Nü Peride was taken with a New Historicist approach and how this theory, which constitutes a different perspective on the discipline of history, manifests in the novel.

Keywords: Postmodernism, New Historicalism, Nü Peride, Hakan Akdoğan.

\section{Giriş}

Toplumun en küçük yap1 taşı olan insanı konu edinen önemli bilim dallarından biri edebiyattır. Yaşanmış ya da yaşanabilir gerçekliği ele alan roman ise toplumun aynası olarak nitelendirilerek edebiyatın en önemli dallarından birini oluşturur. Edebiyatın, özelde romanın malzeme olarak kullandığ bulunmaktadır. Onların başında ise tarih disiplini gelir. Tarih, tıpk1 roman gibi, temelde insanı ve insan kümeleşmesi bağlamında toplumu inceler. Öyle ise tarih ile roman, hedef kitlesinin benzer olmasından kaynaklı bir yakınlık içerisine girer. Bu yakınlık, sosyo-kültürel ve siyasal farklılaşma ile çeşitli şekillerde gerçekleşirken 1980'lerde ülkemizde görülmeye başlanan postmodern akımın tesiri ile son derece büyük bir değişime ev sahipliği yapar.

Postmodernizm kavramı ilk kez, 1979 yılında J. Françoise Lyotard tarafindan yazılmış olan Postmodern Durum adlı eserde kullanılmıştır. "Postmodernlik hakikat, doğa bilimlerinin somutlaştırdığ araçsal ve indirgeyici akıl, kimlik, nesnellik, siralılık ve diyalektikten, evrensel ilerleme ve kurtuluş fikrinden, büyük anlatı ve temel gerçeklikten kuşku duyan bir düşünce tarzıdır." (Möngü, 2013, s. 28). Aydınlanma projesine ve onunla birlikte zuhur eden her türlü düzene karşı çıkan postmodernizm (Sim, 2006, s. 362), gerçekliğin şüpheyle bakılması gereken bir boyut olduğunu savunurken onu tartışılabilir bir mecraya çeker. $\mathrm{Bu}$ bağlamda söz konusu olan eserin ortaya koyduğu bu düşünce tarzı ile birlikte mutlak gerçeklik algısı sarsılmış, kural ve hiyerarşinin toplumdaki yetkinliği tartışılır olmuştur. Kuralsızlık, farklılık, zitlık, belirsizlik gibi eskiden kabul görmeyen ve ötelenen durumlar, artık kabul görür hatta ilgi çeker hâle gelmiştir. Aynı zamanda bu akımla birlikte "özenle oluşturulan anlatımların yanında kaba sözlerin, küfrün, argonun, pornografik ögelerin kullanılmasına tanık olunabilmektedir." (Ertem, 1999, s. 105).

Düzeni bozmak ve kaos ortamı oluşturmak adına ortaya atılan bütün bu düşüncelerin temelinde, Sanayi Devrimi ve İkinci Dünya Savaşı vardır. Zira bu iki önemli olay, dünyada güvensiz bir ortamın doğmasına sebep olur. Güvenilir olmayan bir dünyada ise bilimsel bilgiler dahi sarsılmazlığını yitirir, kural ve ölçütler hiç olmadığı kadar çeşitlenerek değişime uğrar (Lyotard, 1994, s. 64). Tüm bu algı değişimleri, postmodernizmin niteliklerinin farklılaşmasına yol açar. $\mathrm{Bu}$ nitelikleri ise şöyle sıralamak mümkündür:

a) Genelgeçerlik iddiası taşıyan önermelerin reddedilmesi esastır. Gerçeği olabildiğince yorumlamak, belli bir zaman ve mekânın sözcüklerini kullanmak yerine gerçekliği kendi bütünlüğü ve özerkliği içinde anlamaya çalışmak esastır.

b) Gerçekler karmaşıktır.

c) Gerçeklik bütünlük arz etmez ve uyumlu değildir.

d) Bilgi kaynaklarında, bilim topluluklarında, dildeki anlamlarda çoğulculuğun ve parçalanmanın kabul edilmesi esastır.

e) Söylem çoğulluğu benimsenir. Farklılığın ve çeşitliliğin vurgulanıp benimsenmesi; gerçeklik, hakikat, doğruluk anlayışlarının tartış1lmasına yol açan dilsel dönüşümün yaşama geçirilmesi söz konusudur.

f) Mutlak değerler anlayışı yerine yoruma açık seçeneklerle karşı karşıya gelmekten çekinmemek, güvensizlik duymamak esastır.

g) Tek bir doğru yoktur. Tümel ve mükemmel bilgi yoktur. İnsanı ruh-beden olarak ikiye bölen anlayışlarla 
hesaplaşmak, tek ve mutlak doğrunun egemenliğine karşı çıkmak esastır.

h) Gelecek önceden bilinemez.

i) Her nedenin bir sonucu ortaya koyduğunu ifade eden türden tek yönlü bir nedensellik yoktur; sadece karşılıklı etkileşim vardır.

j) Gözlemciyi gözlenenden ayıran bir mesafe yoktur.

k) Nesnellik diye bir şey yoktur (Çağlar, 2008, s. 372).

Postmodernizm akımını benimseyen "Roland Bartles, Jean Baudrillard, Judith Butler, Gilles Deleuze, Luce Irigaray, Charles Jencks, Slavoj Zizek, Paul Feyerabend, Jacques Derrida, Michel Foucault, Julia Kristeva ve Richard Rorty gibi isimler zikredilebilir." (Möngü, 2013, s. 30). Mezkûr postmodernistlere göre pek çok bilim dalı bu düşünce sistemi ile tekrar ele alınmalı ve değerlendirilmelidir. O bilim dallarından biri olan tarih disiplini, postmodernizm ile birlikte gerçek ve nesnel bir anlayıştan uzaklaşarak zaman ve mekân algısını kaybeder. Millî kültür ve geleneksel değerlerin aktarımı ile tarihin sebepsonuç ilişkisi içerisinde değerlendirilmesi bu akım ile ortadan kalkarken her düşüncenin ve tercihin özel olması önem kazanır hâle gelir. Bu aşamada, önemli bir tarih felsefecisi olan Michel Foucault, metinlere işlenerek kayıt altına alınan tarihin, her tarihçi tarafından yeni baştan canlandırıldığını ve yeniden yazıldığını savunur (Foucault, 1999, s. 178). Geleneksel anlayış ile tarihi yüzeysel olarak inceleyip süreç aralığını uzatmak yerine, belirli ve kısa bir dönemi derinlemesine ve yoğunlaşarak incelemenin daha doğru bir değerlendirme metodu olduğunu da savunan Foucault, düşüncelerinin temeline Friedrich Nietzche'nin "gerçek tarih" diye bahsettiği kavramı yerleştirdiği söylenebilir. Ona göre tarihte doğru bilgi diye bir şey yoktur, bu yüzden tarihçilerin nesnellik kaygısı ile metin oluşturma çabaları da yanlıştır (Urhan, 2000, ss. 112-123). Böylelikle gerçek denilen mefhum da daha önce zikrettiğimiz gibi, şüphe ile bakılan bir doğrular manzumesi hâlini alır. Mutlak iyi veya kötünün yerini parçalanmışlık ile çoklu bir yapının alması ise gerçeklik algısında farklı bir karmaşanın oluşmasına sebebiyet verir.
Postmodernistler, tarihi bir malzeme olarak kullanır ve yorumlara dayalı bir tarihin varlığından söz ederek postmodern tarih romanı kavramını ortaya çıkarır. Kurgusal bir tarih yaklaşımı ile kaleme alınan bu romanlarda "tarihin metinselliği / kurgulanabilir bir disiplin oluşu, onun sadece dil (lisan) içerisinde gerçekleşebileceği kabulü, kaydedilmiş gerçeklerin bile tarihçi tarafindan yeniden yorumlanarak ortaya çıkartılması süreci, 'tarih' kavramının geleneksel anlamını temelden sarsmış ve tarihe yeni bir anlam kazandırmıştır." (Yalçın Çelik, 2005, s. 25).

Söz konusu yeni anlayış ve bakış açısı ile birlikte, tarihin eleştirilemez olan tarafı gündeme gelir ve 1980'lerin başında bir eleştiri yaklaşımı mahiyetinde Yeni Tarihselcilik kuramı ortaya çıkar. Amerikalı bir eleştirmen olan Stephen Greenblatt, kuramı ortaya atarak kullanan ilk kişidir. Greenblatt'a göre sanat eserleri "güçlerin çatıştı̆̆ 1 ve sürekli değişen çıkarların söz konusu olduğu alanlardır ve her an devrilme ve yıkılma hissi uyandiran durumlardan ibarettir." (akt. Çavuş, 2001, s. 2250). Söz konusu olan değiş̧im ve çatışmalar odağında toplumda varlığ yadsınamaz bir gerçeklik olan ideoloji, bakış açısı ve hayal gücünün metne dayalı her türlü disiplini etkilediğini savunan Greenblatt, tarih yazımında da somut ve soyut her türlü değişim ve çatışmadan mutlak surette etkilenildiğini belirtir. Yeni Tarihselci akımı destekleyen Hayden White ve Iggers da edebî eser ile tarih arasındaki yakınlıktan söz ederek tarihçilerin her ne kadar kayıtlı belgeyi ilk elden yazarken objektifliğe dikkat etmeye çalışsalar da tarihî süreç içerisinde bir seçmeye gitmek durumunda kalarak bile nesnel olmaktan çıktıklarını düşünürler (Yeşilyurt, 2009, s. 2008).

Resmî belgelerin okunmasından sonra tarihî metinlerin oluşturulma aşamasında, her tarihçi aynı konuya farklı bakabilir ya da onu farklı algılayabilir. Kişinin eğitimi, ailesi, kültürü, ideolojisi gibi pek çok sebepten dolayı değişebilen bu durum, Keith Jenkins'in yeni tarih anlayışına dair şu cümleleri ile hem postmodernistleri hem de Yeni Tarihselcileri desteklemektedir: 
Her kuşak kendi tarihini yazar... Tarih, asla kendisi için değil daima birileri içindir... Tarih kuramdır ve kuram ideolojiktir ve ideoloji maddi çıkarlardır... Bilgi iktidarla ilişkilidir ve toplumsal oluşumlarda en fazla güce sahip olanlar bilgiyi dağıtırlar ve bilgiyi ellerinden geldiğince çıkarlarına göre meşrulaştırırlar... Tarihler birileri içindir... Tarih çalışırken, incelediğimiz geçmiş değil, tarihçilerin geçmiş hakkında oluşturdukları şeylerdir... Bütün tarih geçmişte yaşamış olan insanların akıllarının tarihi olmaktan çok tarihçilerin akıllarının tarihidir (Jenkins, 1997, ss. 30-59).

Yeni Tarihselciler, yaşandığı varsayılan geçmiş ile fazla alakadar olmayarak nesnel bir tarihin varlığını sorgulama ihtiyacı hisseder. "Tarihin bilimsellik iddiası, tarihçinin olayları bir seçme süreci sonucu belli bir düzen içinde anlatıya çevirmesiyle zaten yıkılmaktadır. Yalnızca seçme ve ayıklama işleminin kendisi tarihin ne denli nesnellikten uzak olduğunu göstermektedir." (Oppermann, 1999, s. 8). Bu uzaklık ise tarih ile roman arasındaki çizgiyi ortadan kaldırır ve "metinlerin tarihselliği ve tarihin metinselliği"ni (akt. Çavuş, 2001, s. 123) gündeme taşır. Yeni Tarihselcilik kuramının en önemli isimlerinden olan Louis Montrose, tarihin sadece kayitlı belge ve bulgular üzerine inşa edilemeyeceğini, o belgelerin oluşumunda dahi bir kültür ve ideolojinin söz konusu olduğunu, bu nedenle roman gibi yorumlanarak değerlendirilmesi gerektiğini savunarak Derrida'nın "metnin dışında hiçbir şey yoktur." (akt. Fırıncı Orman, 2015, s. 72) görüşünü destekler.

Yeni Tarihselcilik kuramı kronolojinin takip edildiği, padişah, paşa gibi devlet büyükleri ile fetih ve savaş gibi önemli olayların ele alındığı, okuyucunun romanın sonunu tahmin edebildiği, tarihî bilgi verme amaciyla oluşturulan geleneksel / kronolojik / klasik tarih anlayışına karşı çıkar. Tarihin gizli kalmış, ötelenmiş, önemsenmemiş belki de saklanmış olan tarafları ise bu kuramın asıl ilgi alanına girer (akt. Çavuş, 1998, ss. 34, 35). Böylece edebî metnin oluşturulma aşamasında bu yeni tarih anlayışından yararlanılarak farklı bir tavır sergilenmiş olunur.

\section{Yöntem}

Edebiyat metinleri, bilimsel bir değeri ortaya koyarken sanatsal malzemeyi kullanır. Bu değer, rastgele metne yerleştirilmiş ve direkt okuyucu ile paylaşılan bir değer değildir. Aksine belirli bir yöntem dâhilinde metne yerleştirilen ve "metin tahlili / çözümleme" yönteminin kullanılması ile ortaya çıkacak olan bir değerdir. Bu yöntem anlama, yorumlama, parçalara ayırma ve analiz etme şeklinde gerçekleşir. Bir edebiyat metni olan romanın da bu yaklaşımlar ile değerlendirilmesi neticesinde "kuramsal bir temele dayanan bilişsel ve k1lgisal bir etkinlik" (Öztokat, 2005, s. 11) gerçekleştirilmiş olur.

Çalışmamıza esas olan Nü Peride romanı ise tarih ile roman / gerçek ile kurgu arasındaki sınırı âdeta ortadan kaldıran bir postmodern tarih romanı olarak karşımıza çıkar. Bu romanın söz konusu değerlendirme yöntemi ile analiz edilmesi, "Yeni Tarihselcilik" kuramının edebiyat metinlerinde nasıl somutlaştığının ortaya konulması bakımından önemlidir.

\section{Yeni Tarihselcilik ve Nü Peride}

Postmodern kurgu ile kaleme alınmış olan $N \ddot{u}$ Peride, iki farklı bakış açısı ve anlatıcı ile oluşturulmuştur. Onlardan biri ilahi bakış açısı ile üçüncü tekil kişi anlatıcısı olan "o", diğeri ise birinci tekil kişi anlatıcısı olan "ben" ile kahraman bakış açısıdır. $\mathrm{Bu}$ değişimin başlıca sebebi ise romanın üstkurmaca özelliğe sahip olmasıdır. $\mathrm{Bu}$ özellik bağlamında ilerleyen iki farklı zaman dilimi ve üç farklı olay örgüsü mevcutken buna bağl1 olarak romanda var olan üç kurgusal düzlemden bahsedilebilir. İlki Necati'nin hayal dünyasıdır; ikincisi romanın kendi dünyası yani Necati'nin anlattığı ressam Halil ile Ermeni Ante'nin dünyas1; sonuncusu ise romanın sonunda ortaya çıkan dünyadır. Kurmaca içinde kurmaca olarak varlık gösteren söz konusu durum hem yaşanan zaman diliminin hem de gerçek-düş ayrımının ortadan kalkarak okuyucunun fikrî bir karmaşa içine girmesine sebep olur. Postmodernizmdeki kurgu ile gerçekliğin birbiri içinde ilerlemesi neticesinde ortaya çıkan kaos ortamı ise Yeni Tarihselci yaklaşımın tarih ile 
edebiyat arasındaki ayrımın silikleştirilmesi şeklinde somutlaştığını göstermektedir.

Roman üstkurmaca metnin anlatıcıs1 olan Necati'nin zaman diliminde yani bugünde, k1z arkadaşı olduğunu öğrendiğimiz Beril ve sevgilisi Nevtan'dan intikam alma isteğinin tasviri ile başlar. Necati, tekerlekli sandalye kullanmak zorunda olan biridir. Sevdiği k1z olan Beril'in s1k s1k kendisini ziyarete gelmesinden önceleri mutlu olur; fakat sevgilisi olduğunu öğrendiğinde büyük bir üzüntü içine düşer ve Beril'in kendisine acıdığı için yanına geldiğini düşünmeye başlayarak hem Beril'e hem de onu kendisinden kopardığını düşündüğü Nevtan'a düşmanca duygular beslemeye başlar. $\mathrm{Bu}$ yüzden Necati, Beril ve Nevtan'dan intikam almak ister. Roman boyunca, Necati'nin intikamını alacağı günün gelmesini büyük bir arzu ile bekleyişine şahit oluruz. Beril kendisini ziyaret ettiği için ona ulaşmakta sorun yaşamayan Necati, Nevtan'a da ulaşabilmenin planlarını yapar. $\mathrm{Bu}$ amaçla kendisini ziyarete gelen Beril'e, sevgilisi Nevtan'a bahsedeceğini tahmin ettiğinden dolayı bir hikâye anlatmaya başlar. Nevtan'a ulaşma aşamasında nasıl bir plan kurguladığını ise okuyucu ile şöyle paylaşır:

Oysa ben bu adamla ve ilişkinizle ilgilendiğim için değil, günün birinde intikam alabilmek için soruyordum bana dayanılmaz acılar veren o soruları. (...) Sonunda Ermeni Ante adında birisine ait bir öyküyü araştırdığını öğrendim. Tek ortak noktamızd. Bu tek ortak nokta geçmişte, ta Osmanlı'da birleşiyordu. Yıllarımı verdiğim ressam Halil'in yaşamöyküsünde geçen Ermeni Ante ile aynı kişiydi bu ve Nevtan bir yerlerde tıkanıp kalmıştı. Bunu anladığımda intikam planım için başlangıç noktasını buldum. Senin aracılığınla Nevtan'a Ante'nin yaşamıyla da ilgisi olan Halil'in öyküsünü ulaştırdım. Beklediğim gibi sen Nevtan'a öyküyü anlattın, Nevtan da buraya geldi (Akdoğan, 2002, s. 105).

Hikâyeyi büyük bir merakla dinleyen Beril, Necati'nin hayal gücüne olan hayranlığını dile getirirken düş ile gerçek ayrımındaki sınırların onun hafizasında ortadan kalktığını şöyle gözler önüne serer: "-İşte en sevdiğim yanın. Öylesine inanıyorsun ki düşlerine, sonunda gerçek ile kurmacayı karıştırıyorsun. Ama gönüllü yapiyorsun bunu. Bilerek kat1lyorsun bu kandırmacaya." (Akdoğan, 2002, ss. 49, 50).

Necati hikâyeyi kendi yaşadıkları zaman diliminde geçiyormuş gibi kurgular. Okuyucu önce herhangi bir tarihî zaman çelișkisine düşmezken Şemsi Ahmed Paşa isminin zikredilmesi ile gerçek-düş karmaşası içine girer. Bu karmaşa, anlatılan hikâye ile anlatıcı Necati'nin oluşturduğu bir kaos ortamıdır. Necati'nin söylediği şu cümleler ise gerçek ile kurgunun ayrımında okuyucudan önce anlatıcının zihninin bulandığını göstermektedir:

Düş gücümdeki inanılmaz artış yaşamımı etkilemeye başlamıştı. Geçmişe ait ufacık bir anımsama gerçeğin içine kurmacayı da katarak hayallememe sebep oluyordu. Kimi zaman kurmaca bir mekân, geçmişte bulunduğum gerçek bir mekândan daha yaşanmış geliyordu. Karışıyordu, karıştırıyordum. Gerçeklerden, kurmaca zaman- mekân'a doğru kaçıyordum. Hangisinin daha gerçek olduğunu bulamıyordum. - Belki de düşlerdir gerçek olan! (Akdoğan, 2002 s. 25).

Düşsel yaşamım gerçek yaşamımı gölgelemeye başlamıştı (Akdoğan, 2002 s. 35).

Söz konusu düş-gerçek ayrımını oluşturan temel unsurlardan bir diğeri ise romanın zaman dilimi olarak Osmanlı Devleti'nin Şemsi Ahmed Paşa 'nın görev yaptığı III. Murat dönemi ile Necati'nin yaşadığı dönem arasında değişmesidir. Anlatılan hikâye ile ortaya çıkan zamansal kaos ortamı ise Bakhtin'in 'karnaval' benzetmesi ile daha belirgin hâle gelir. Bu benzetmeye göre "Yazınsal dil, ister sözlü ister yazılı olsun, bizzat bir anlatım sistemi olarak sergilediği boyut açısından katmanlaşmıştır ve bu yönüyle çok söylemli bir yapıdadır." (Bakhtin, 2014, s. 64). Romanda da olay örgüsü günümüz ile Osmanlı dönemi arasında sürekli değişmekte ve hem yaşanan olayların hem de kişilerin gerçek-kurgu ayrımı yapılmasını zorlaştırmaktadır. Böylece zorunlu bir karnaval ortamı ile muhatap olmak durumunda kalan okuyucu, romanın sonuna geldiğinde anlatıcının "Eşitiz, aynıyız. Ama o elma olmasaydı yine eşit olacaktık. Değer miydi bir elmaya?" (Akdoğan, 2002, s. 110) sorusu ile karşı karşıya kalır ve 
anlatıcı da okuyucunun zihni bulanıklığını bir kat daha arttırarak gerçeklik kavramını sorunsallaştırır. Buradaki tarihsel sürecin anlatıcı Necati tarafindan algılanması ile Beril'e aktarması, Beril'in okumas1 ile okuyucunun algilamas1 arasında tamamen bir benzerlik mevcut değildir. $\mathrm{Bu}$ nedenle ele alınan tarih, nesnellikten uzaklaşarak anlatıcının öznel tarihi hâline gelir. Dolayisiyla bu durum, Yeni Tarihselcilerin tarihî metinlere geleneksel anlayışın dışında yaklaşması ile örtüşmektedir.

\section{Parçalıık / Parçalanmışlık}

Parçalanmışlık kavramı postmodernizm ile birlikte gündeme gelen bir durum analizidir. Yeni Tarihselciler ise olgulardan ziyade olaylarm parçalanmışlı̆g 1 ile ilgilenir. Onlara göre tarih tek bir çizgide siralı olarak zuhur etmez. Aksine geçmiş-an-gelecek an'da birleşerek çizgisel bir tarih anlayışının dışına çıkar ve parçalanmış tarihî vakalar bir arada gerçekleşir. $\mathrm{Bu}$ durumun romandaki tezahürü, Necati'nin yaşadığı dönem ile anlattı̆g1 hikâyedeki dönemin ve olayların birbirinden farklı olmasına rağmen beraber ilerlemesi şeklinde görülmesidir. Söz konusu süreklilik, tarihin tek bir kronolojiyi takip ederek sıralı ilerlemesinin mümkün olamayacağı görüşü ile Yeni Tarihselcileri desteklemektedir. Farklı zaman dilimi ve mekânlarda bulunan kişilerin tema bakımından farklı olayları yaşamaları, parçalanmış tarihî vakalar olarak okuyucunun karşısına çıkar.

Nü Peride romanında Şemsi Ahmed Paşa'nın müstakbel damat adayı Ermeni Ante'nin hayat hikâyesi ile aynı dönemde yaşadığı varsayılan ressam Halil'in nü resim çizme saplantısı ile başına gelenler bir arada verilmiştir. Aynı dönemde yaşayan Ressam Halil ile Ermeni Ante'nin yolları, Halil'in ihtiyacı olan boyaları almak için Ermeni Ante'nin dükkânına gitmesi ile kesişir. Halil'in hayallerini gerçekleştirmek için resim yaptığı ev ise anlatıcı Necati'nin evidir. Üç farklı olay örgüsünün oluşturduğu bu heterojen yap1, Necati'nin evinde bir bütün hâline gelir ve zaman dilimleri bu mekân dâhilinde iç içe ve yan yana eklenir.
Söz konusu kesişme, bir nevi metin-bağlam-insan kesişmesidir. Nitekim bağlamı oluşturan tarihî evin ortak kullanılması, bağlam ile insanın temasina delildir. Metin ise bu iki unsurun etkileşimi neticesinde ortaya çıkan üründür. Parçalanmış olayların bir arada gerçekleşebiliyor olmas1, Yeni Tarihselcileri tarihin kronolojik olarak ilerlerken sıralı bir çizgiyi takip ettiği düşüncesini reddetmesine sebep olur. Bu minvalde tarih, geleneksel tarihçilerin ele aldığı gibi temiz bir bütün değil, parçalanmış bir bütündür. $\mathrm{Bu}$ parçall1ık ise tarihle ilgilenen, okuyan herkesçe farklı algılanacak bir durum teşkil eder. Zira Yeni Tarihselciler de bu görüş doğrultusunda, tarihin bilimsellikten ziyade yorumsallığına / metinselliğine dikkatleri çekerek gerçeklik boyutunun sarsılmasina müsaade etmeyen geleneksel tarih anlayışının sorgulanabilir ve eleştirilebilir bir disiplin alanı olduğunu savunur.

\section{4. Çoğulculuk}

Yeni Tarihselcilik kuramı çelişki, zıtlı ve farklı1ı̆̆ önemseyerek sıradan olana tepkili yaklaşır. Kurama göre her bireyin özel olması, tercihlerinin de özel olması anlamına gelmektedir. Nitekim, parçalanmış olan bireylerin hayatlarından bahsedilen romanda, toplum tarafindan ötekileştirilmiş, dışlanmış ve hor görülmüş kişilerin varlığından haberdar edilerek onların normalleştirildiği; konuşmaktan çekinilen konu ve durumların ise konuşulur hâle gelerek ortaya çıkarıldığı görülmektedir.

Roman kahramanı olan Ressam Halil'in nü resim çizme saplantısının olması romanda üzerinde durulması gereken ilk psiko-sosyal durumdur. Zira Halil, pek çok kadının resmini çizer; fakat o hem gözüne hem gönlüne hitap eden kadının çıplak resmini çizmeyi düşlemektedir. Hayalleri uğruna birkaç girişimde bulunur, hatta yaşanan tarihî süreçte sosyo-kültürel şartlardan dolayı erkekkadın ilişkilerinin zor gelişmesi onun farklı yollara başvurmasına sebep olur. Anlatıcının Halil'in saplantılı ruhunu yansıttığı şu cümleleri, resim çizmekten uzaklaşan bir ressamın tekrar o sanat zevkine geri dönebilmek adına gerçekleştirdiği normal bir durum olarak tasvir edilir: "Halil'in kadın bedeni çizme tutkusu yaşama amacı haline 
gelmişti, ama içinde bulunduğu ortamda bunu başarabilmesi neredeyse olanaksızdı. Çareler düşünüyor, bulamıyordu. Artık bir şey çizemez olmuştu. İlla ki kadın bedeninin önünde ve tabloya yalnızca bu aktarılmalıydı." (Akdoğan, 2002, s. $31)$.

Roman Halil'in bu düşü ile ilerlerken tutkusuna yenik düşerek bir hamamın çatısında açtığı küçük bir delikten, hamama gelen kadınları gözlemeye başlaması ile devam eder. Gördüğü manzara, ona günlerce yetecek resim malzemesi sunmaktadır. Lakin Halil, kadınların hiçbirisine karşı ilgi duymaz. Umutsuzluğa düştüğü birgün "gözetlediği bir kadın soluğunu daraltı[r], tüyleri diken diken ol[ur]. Durup dururken titremeye başla[r]. Kadının yüzünü beynine kazı[r]." (Akdoğan, 2002, s. 33).

Halil kendisini etkisi altında bırakan bu kadının Peride isimli bir kızcağız olduğunu öğrenir ve ona ulaşmak için türlü oyunlara girer. Onu izlemeye başladığı birgün ise kaçırarak kendi evine götürür. Halil'in tek arzusu, Peride'nin çıplak bir resmini çizmektir. $\mathrm{Bu}$ amaç uğruna kaçırdığı Peride'yi bayıltır ve üzerindeki giysileri çıkartarak resmini çizmeye başlar. Anlatıcı Necati, Halil'in resim çizme olayını şöyle tasvir eder:

Halil baygın yatan kızı bir süre seyretti. (...) Sonra koltukta yatan Peride'ye yaklaştı. İncitmekte korkarak ince feracesini sıyırdı üzerinden. Kadife entarisini de yumuşak hareketlerle çıkardıktan sonra beline bağladığ kuşağ1 çözdü. İpekten biçilmiş iç gömleğinin düğmelerini açtı. Kollarını yukarı kaldırarak gömleği de aldı. Şalvarını çıkardı bacaklarından. Yalnızca çamaşırları kalmıştı üzerinde. Heyecandan yutkunamiyordu. Yıllardır beklediği ana, Peride'nin çamaşırlarını çıkardıktan sonra kavuştu. Kutsal bir iş yapıyormuşçasına mumlardan birkaçını Peride'nin yattığı koltuğun uçlarına yerleştirdi. Dinî bir törendeymişçesine boyalarını hazırladı. Elleri titreyerek resmi çizmeye başladı (Akdoğan, 2002, s. 38).

Romanın isminden de anlaşılacağı üzere Halil'in nü resim çizme tutkusu, beğendiği kızı kaçırıp bayılttıktan sonra ayin niteliğinde bir resim çizme işlemine girişmesi ile gerçekleşir. Ve bu tutkunun romanda açıkça ifade ediliyor olması, bu tür davranışların sıradan olarak görülmesinin bir neticesidir.

Bir diğer çoğulculuk unsuru ise intikam duygusu ile ortaya çıkan şiddet meylidir. Necati, Beril'in kendisini ziyaret etmesine hem onu gördüğü için mutlu olmakta hem de ona acıdığı için görüşmeye devam ettiğini düşünerek öfkelenmektedir. Ve bu yüzden önce Beril'den, sonra Beril'i kendisinden uzaklaştıran Nevtan'dan intikam almaya karar verir. $\mathrm{Bu}$ intikam düşüncesi ve buna bağlı olarak ortaya çıkan şiddet ile işkence meyli, daha önce konuşulmasının uygun görülmediği, konuşanların ise psikolojik baskılar ile susturulduğu saplantılı bir ruh hâlinin neticesidir. Nevtan'dan alacağ 1 intikamın kendisini tatmin etmesi gerektiğini düşünen Necati, düşsel bir dünyaya yönelir ve yapacağ işkenceleri hayal ederek şöyle betimler:

Ante ile Halil'in öykülerini anlatırken ona verdiğim içkiye çok miktarda uyku ilacı katacaktım. Öyküm bitmek üzereyken gözleri kapanacak, başı düşecek, ama o yine de uyanık kalmaya çalışacaktı. Sonunda çaresiz sızacaktı. Ben de onu bağlayacaktım. Uyandığında mahzendeki mum 1şıkları altında ayinsel bir ortamda bulacaktı kendini. Kıpırdayamayacak, ona yapacaklarıma çaresiz boyun eğecekti. Tabiî önce tehditler savuracaktı, ama uzun sürmeyecekti. Nevtan'ın çıplak bedenini renk renk boyayacak, saçlarını kazıyacaktım. Belki de ilk kez meydana çıkacak olan kafa derisi akıttığım mumlarla yanacaktı. Sonra seni elimden almasını ne kadar ağır ödeyeceğini anlamaya başlayacaktı. Bedeninin birçok yerine diktiğim mumlar her kıpırdanışında sıcak sıvılarını akıtacak, canını yakacaktı. Seni zevkten çıldırtan erkeklik organına gelecekti sıra. Senin bana erkek değilmişim gibi davranmanı, belki de acımanı ödeyecekti Nevtan. Hazırladığım onlarca buz torbasını yerleştirecektim bacak arasına, erkeklik organının üstüne, altına. Buzlar erkekliğini hissetmesini engelleyecekti. Böylece eşit olacaktık. (...) (Akdoğan, 2002, s. 106). 
Benzer bir durum ise Necati'nin Beril'den alacağı intikamda da görülmektedir. Özellikle buz ve mum ile yaptığı işkenceden dolayı verdiği eziyeti gördükçe daha çok zevk alan Necati'nin asıl amacı Beril'i öldürmek değildir. Kendisine acıdığını düşünmesi ve Nevtan'la birlikte olmasından dolay1 canı çok yanan Necati, Beril'in de aynı hissi duymasını ister ve işkenceyi bilinçli olarak bel altına yönelik gerçekleştirir. Beril'in ancak bu şekilde kendisini anlayabileceğini düşünen Necati, duygu ve düşüncelerini şöyle anlatır:

Beril'in ölmesi beni üzerdi. Bundan sonra benim tattığım acıları tadacak. Nevtan bir süre sonra onu terk edecek ve tümüyle yalnız kalacak. Camının önünde oturup baharların gelmesini bekleyecek; baharlarda penceresine konan kelebekleri yakalamayı öğrenecek, sonra da kurutmayı. Sokaklarda koşan çocuklardan nefret edecek zamanla. Kimi zaman ölmek isteyecek ve kendini öldürmeye yeltenecek. Düşünecek, hep düşünecek. Bir elma uğruna bunca şeyi yaşamaya değer miydi? Canı sevişmek isteyecek, beceremeyecek. Becerse bile kendisini becerecek adam bulamayacak. Belki para verecek serserilere, bu iş için. Kendisini arada bir ziyaret edecek Nevtan için aylarca hediyeler hazırlayacak. Nevtan'a yanaşacak kendisiyle sevişmesi için (Akdoğan, 2002, s. 110).

Alıntılarda da görüldüğü gibi hem intikama bağl1 olarak gelişen işkence arzusu hem cinsellik hem de nü resim çizme tutkusu, geleneksel tarih anlayışında toplum tarafından yadsınan ve görmezden gelinerek arka plana atılan konular arasında bulunmaktadır. Bu konular, modernizm ile birlikte konuşulmaya başlanırken postmodernizm ile sıradanlaşır ve yeme, içme gibi normal bir durum olarak algılanmaya başlanır. Tarihin görünen ve belgelerle kayıtlı olan bölümlerinin dışında kalan ve insaniyetin temel özellikleri olarak var olan bu tür duygu ve ihtiyaçlardan bahsedilmesi ise Yeni Tarihselcilik kuramındaki farklı olanı öne çıkarma ve normalleştirme algısını destekler niteliktedir. Aynı zamanda kayıtlı olan tarihin dışında kalan duygu ve düşünce dünyası da tarihin metinselleşerek yoruma dayalı bir algıya bürünmesine sebep olan önemli etmenlerdendir.

Tarihin metinlere dayalı oluşum şeklini irdeleyen Yeni Tarihselcilik kuramı, gerçeklik üzerine yaptığ1 sorgulamalarda çok sesli olan yapıyı kendisine uygun görür. Zira kurama göre bireyin parçalanmışlığı çok sesliliği doğurur. Böylelikle tarihin bir senfoni olarak pek çok kişi nezdinde farklı yorumlanabileceği hem metinsellik hem de öznellik bağlamında ortaya çıkmış olur.

\section{Sonuç}

Yeni Tarihselcilik kuramına göre tarih, yalnızca tarihçiler tarafindan oluşturulan, onların yorumları ile kurgulanan, kayıtlı belgelere dayalı bir disiplin değildir. $\mathrm{Bu}$ disiplin her ne kadar belge temelli olsa da okuyana göre değişiklik gösteren bir metin olarak karşımıza çıkar. "Metin dışında hiçbir şeyin" olmaması ise tarihçileri romancılara yaklaştıran en önemli özelliktir. Metnin nesnel olarak okunmasının mümkün olamayacağını savunan Yeni Tarihselciler, geleneksel anlayıştaki gibi tarihi amaç olmaktan çıkararak araç hâline getirir.

Nü Peride romanında ise postmodernizmin tesiri ile geçmişe yönelen yazar, tarihi yalnızca anlatacağı olay örgüsünü somutlaştırmak adına dekor olarak kullanmıştır. Aynı zamanda romanı kurgularken tarihî zaman dilimi, kişiler ve mekân gibi yap1 unsurlarını malzeme olarak kullanmanın yanında, geçmiş ve geleceği an'da birleştirerek yeni bakış açılarını ortaya koymuştur. Roman gerçeklikten payına düşeni nasıll ki "eleştirilme ve sorgulanma" ile alıyorsa tarih de kurgu ve gerçekliğe dair aynı sübjektif bakış açısını bünyesinde barındırmaktadır. $\mathrm{Bu}$ nedenle tarihî roman olan Nü Peride, tarihî olay ve kişiler bakımından gerçek-düş ayrımının zorlaştığı bir eserdir. Yazar, elinde var olan tarihî malzemeyi yeniden okur, yorumlar ve kurgulayarak eserini oluşturur. Bunu yaparken de tarihin arka sayfalarında kalan kısımlarını ortaya çıkarır, değerlendirir ve birey üzerinde parçalara ayırarak işler. Buradaki asıl amaç ise tarihin de roman gibi kurgulanan bir disiplin olduğunu göstermek, nesnelliğin söz konusu olamayacağını vurgulamak ve tarihi edebiyat düzlemine çekerek gerçeklik 
algısını yıkmaktır. Netice itibariyle, Yeni Tarihselcilik kuramının "metin" ve "yorum" bağlamında ortaya koyduğu bakış açısının $N \ddot{u}$ Peride romanında somutlaştığı görülmektedir.

\section{Kaynakça}

Akdoğan, H. (2002). Nü Peride. (8. baskı). İstanbul: Doğan Kitap.

Bakhtin, M. (2014). Karnavaldan Romana Edebiyat Teorisinden Dil Felsefesine Seçme Yazılar. (C. Soydemir, çev.). (2. bask1). İstanbul: Ayrıntı Yayınları.

Çağlar, N. (2008). Postmodern Anlayışta Siyaset ve Kimlik. S. Demirel Üniversitesi Iktisadi ve İdari Bilimler Fakültesi Dergisi, 13 (3), 369-386.

Çavuş, R. (2002). Edebiyat İncelemelerinde Tarihe Yeni Bir Dönüş. Ankara Üniversitesi Dil ve Tarih-Coğrafya Fakültesi Dergisi, 42 (1-2), 121-133.

Ertem, C. (1999). Türk Romanında Modern Arayışlar ve Post-modernizm. 2000 Yllında Türk Öykü ve Roman Sempozyum Bildirileri, Ankara: Tömer Yayınları.

Fırıncı Orman, T. (2015). Jacques Derrida Düşüncesinde 'Dil'. Kilikya Felsefe Dergisi, 1, 61-81.

Foucault, M. (1999). Bilginin Arkeolojisi. (V. Urhan, çev.). İstanbul: Birey Yayıncılık.
Jenkins, K. (1997). Tarihi Yeniden Düşünmek. (B. S. Şener, çev.). Ankara: Dost Kitabevi.

Lyotard, J. F. (1994). Postmodern Durum. (A. Çiğdem, çev.). Ankara: Vadi Yayınları.

Möngü, B. (2013). Postmodernizm ve Postmodern Kimlik Anlayışı. Atatürk Üniversitesi Sosyal Bilimler Enstitüsü Dergisi, 17 (2), 27-36.

Oppermann, S. (1999). Postmodern Tarih Kurami: Tarihyazımı Yeni Tarihselcilik ve Roman. Ankara: Evin Yayıncilik.

Öztokat, N. T. (2005). Yazınsal Metin Çözümlemesinde Kuramsal Yaklaşımlar. İstanbul: Multilingual Yayınevi.

Sim, S. (2006). Postmodern Düşüncenin Eleştirel Sözlüğü. (M. Erkan \& A. Utku, çev.). Ankara: Ebabil Yayınları. (Orijinal çalışma 2001'de yayımlanmıştır).

Urhan, V. (2000). Michel Foucault ve Arkeolojik Çözümleme. İstanbul: Paradigma Yayıncılık.

Yalçın Çelik, S. D. (2005). Yeni Tarihselcilik Kuramı ve Türk Edebiyatında Postmodern Tarih Romanları. Ankara: Akçağ Yayınları.

Yeşilyurt, Ş. (2009). Nedim Gürsel'in Romanlarının Yeni Tarihselci Bağlamda Okunması. Turkish Studies, 4 (1-II), 1990-2009. 